\title{
The Equilibrium Constant of the Isocitrate Dehydrogenase Reaction
}

\author{
BY J. C. LONDESBOROUGH AND K. DALZIEL \\ Department of Biochemistry, University of Oxford
}

(Received 19 June 1968)

\begin{abstract}
1. The equilibrium constant for oxidative decarboxylation of isocitrate by NADP ${ }^{+}$, catalysed by isocitrate dehydrogenase, was measured in solutions of various ionic strengths and at several temperatures. 2. Thermodynamic values for the reaction were obtained by extrapolation to zero ionic strength, and the heat of reaction was estimated. 3. The effect of $\mathrm{Mg}^{2+}$ ion concentration on the equilibrium was studied.
\end{abstract}

The equilibrium constant for the oxidative decarboxylation of isocitrate by $\mathrm{NADP}^{+}$was estimated by Ochoa (1948) as the mean of values obtained at room temperature with various bicarbonate concentrations. The value has been used to calculate standard free-energy data for the reaction (Burton \& Wilson, 1953; Burton \& Krebs, 1953; Burton, 1957). In the present work, the effects of ionic strength, temperature and $\mathrm{Mg}^{2+}$ ion concentration on the equilibrium were studied to determine the equilibrium constant under defined conditions for kinetic experiments and under physiological conditions, and to obtain more precise estimates of standard thermodynamic quantities.

\section{MATERIALS AND METHODS}

Enzymes. Isocitrate dehydrogenase [threo- $\mathrm{D}_{\mathbf{s}}$-isocitrate$\mathrm{NADP}^{+}$oxidoreductase (decarboxylating), EC 1.1.1.42] was prepared from ox heart mitochondria by $\left(\mathrm{NH}_{4}\right)_{2} \mathrm{SO}_{4}$ fractionation, precipitation with nucleic acid, acetone fractionation and a second $\left(\mathrm{NH}_{4}\right)_{2} \mathrm{SO}_{4}$ fractionation. The specific activity was $25 \mu$ moles of $\mathrm{NADP}^{+} / \mathrm{min} . / \mathrm{mg}$. of protein in the assay described by Siebert, Dubuc, Warner \& Plaut (1957), which is about half that of the pig heart enzyme isolated by these workers, and twice that of the preparation described by Rose (1960). The enzyme preparation was free from aconitase, glutamate dehydrogenase, NAD. linked isocitrate dehydrogenase and NADPH oxidase activities. Stock solutions of $10 \mathrm{mg}$. $/ \mathrm{ml}$. in $0.05 \mathrm{M}$-sodium phosphate buffer, pH 7.4, containing $1 \mathrm{mm-EDTA}$ and $10 \%(\mathrm{w} / \mathrm{v})\left(\mathrm{NH}_{4}\right)_{2} \mathrm{SO}_{4}$, were stable at $2^{\circ}$. For use, solutions containing 1-2mg./ml. were freshly prepared by dilution with the same buffer containing EDTA but no $\left(\mathrm{NH}_{4}\right)_{2} \mathrm{SO}_{4}$.

Ox liver glutamate dehydrogenase was obtained from C.F. Boehringer und Soehne G.m.b.H. (Mannheim, Germany) as a crystalline suspension in $2 \cdot 8 \mathrm{M}-\left(\mathrm{NH}_{4}\right)_{2} \mathrm{SO}_{4}$.

Coenzymes. These were obtained from Boehringer Corp. (London) Ltd. (London, W. 5). NADP+ was assayed spectrophotometrically with isocitrate dehydrogenase. The reaction mixture contained, in $3 \mathrm{ml} ., 80 \mu \mathrm{moles}$ of trischloride buffer, $\mathrm{pH} 7 \cdot 4,16 \mu$ moles of DL-isocitrate, $4 \mu \mathrm{moles}$ of $\mathrm{MgSO}_{4}, 1 \mu$ mole of EDTA and about $0.2 \mu$ mole of NADP + . With $10 \mu \mathrm{g}$. of enzyme the reaction was complete $(99.95 \%)$ in $5 \mathrm{~min}$.

NADPH was assayed by complete oxidation with 2-oxoglutarate and glutamate dehydrogenase. The reaction mixture contained $100 \mu$ moles of sodium phosphate buffer, $\mathrm{pH} 7 \cdot 4,3 \mu \mathrm{moles}$ of 2 -oxoglutarate and about $0.15 \mu \mathrm{mole}$ of NADPH in $3 \mathrm{ml}$. With $10 \mu \mathrm{l}$. of crystalline enzyme suspension in $2 \cdot 8 \mathrm{M}-\left(\mathrm{NH}_{4}\right)_{2} \mathrm{SO}_{4}$ the reaction was complete in $10 \mathrm{~min}$. The residual extinction at $340 \mathrm{~m} \mu$ was $1 \%$ of the initial value (cf. Dalziel \& Dickinson, 1965).

Substrates. DL-Isocitrate was obtained as the trisodium salt from Sigma Chemical Co. (St Louis, Mo., U.S.A.). It was assayed with isocitrate dehydrogenase as described for NADP+, except that $0.7 \mu$ mole of NADP+ and about $0 \cdot 2 \mu$ mole of $\mathrm{DL}$-isocitrate were used.

2-Oxoglutaric acid from Koch-Light Laboratories Ltd. (Colnbrook, Bucks.) was recrystallized from acetonebenzene. Solutions were neutralized with $\mathrm{NaOH}$ and assayed with glutamate dehydrogenase. The reaction mixture contained, in $3 \mathrm{ml}$., $100 \mu$ moles of sodium phosphate buffer, $\mathrm{pH} 7 \cdot 4,0.25 \mu$ mole of NADH and about $0.15 \mu$ mole of 2-oxoglutarate. The reaction was complete in $10 \mathrm{~min}$. with $10 \mu$ l. of enzyme.

It was shown by enzymic analysis that the 2-oxoglutarate was free from isocitrate $(<0.05 \%)$ and that the isocitrate was free from 2 -oxoglutarate $(<0.5 \%)$.

The $\mathrm{CO}_{2}$ was introduced into the reaction mixtures by equilibration at atmospheric pressure either with the pure gas obtained from a Thermos flask containing solid $\mathrm{CO}_{2}$ or with $\mathrm{CO}_{2}+\mathrm{N}_{2}$ (5:95) from a cylinder (British Oxygen Co. Ltd.). The latter was kindly analysed by $\mathrm{Dr} N$. K. Bhattacharyya in the Department of Physiology, Oxford, and the $\mathrm{CO}_{2}$ content was $5 \cdot 24 \%$.

Buffer and salts. Salts were A.R. grade from British Drug Houses Ltd. (Poole, Dorset). Reaction mixtures were buffered at $\mathrm{pH} 6 \cdot 6-7 \cdot 2$ by the addition of the appropriate concentration of $\mathrm{KHCO}_{3}$, calculated from the dissolved $\mathrm{CO}_{2}$ concentration and $\mathrm{p} K_{1}^{\prime} 6.4$ for $\mathrm{H}_{2} \mathrm{CO}_{3}$. The ionic strength was varied by the addition of $\mathrm{KCl}$. It was confirmed that the equilibrium constant, expressed in terms of dissolved $\mathrm{CO}_{2}$, is independent of $\mathrm{pH}$ over this limited range 
at constant ionic strength. Greater variation of $\mathrm{pH}$ was prohibited by coenzyme instability and most measurements were made at $\mathrm{pH} 6 \cdot 9-7 \cdot 2$.

Except in experiments on the effect of $\mathrm{Mg}^{2+}$ ion concentration, $0 \cdot 133 \mathrm{~mm}-\mathrm{MgSO}_{4}$ was present in all reaction mixtures to supply the essential metal ion for the enzyme.

The ionic strengths of the reaction mixtures were calculated from the concentrations of $\mathrm{KHCO}_{3}, \mathrm{KCl}, \mathrm{MgSO}_{4}$ and 2-oxoglutarate. The contributions of isocitrate, coenzymes and enzyme were neglected.

Equilibrium measurements. Water and stock solutions of $\mathrm{KHCO}_{3}$ and $\mathrm{KCl}$ used to make up the reaction mixtures were first saturated with $\mathrm{CO}_{2}$. Reaction mixtures, without enzyme and coenzyme, were made up in quartz cells (optical path $1 \mathrm{~cm}$.), sealed with Parafilm, and brought to the required temperature in a water bath. $\mathrm{CO}_{2}$ was passed first through water at the same temperature and then into the reaction mixture by means of a Teflon tube ( $1 \mathrm{~mm}$. bore) that passed through a hole in the Parafilm to the bottom of the cell. After $15 \mathrm{~min}$. the tube was withdrawn, coenzyme was added and the cell was sealed again. The extinction at $340 \mathrm{~m} \mu$ was measured in a Zeiss spectrophotometer (model PMQII), equipped with a thermostatically controlled cell housing. Enzyme $(10 \mu \mathrm{l}$.) was then added to the $3 \mathrm{ml}$. reaction mixture, the cell was returned to the water bath, and $\mathrm{CO}_{2}$ was again passed until the extinction at $340 \mathrm{~m} \mu$ reached a constant value.

To minimize coenzyme breakdown, relatively large amounts of enzyme (15-50 $\mu \mathrm{g}$.) were used so that equilibrium was reached in $5 \mathrm{~min}$. at low ionic strengths, and in $15 \mathrm{~min}$. at high ionic strengths, which inhibit the enzyme.

No significant variation of the equilibrium constant with the enzyme concentration was observed. Once equilibrium was reached the extinction in the sealed cell remained constant even without gassing for several minutes if the surface of the solution was not disturbed. To avoid excessive pressure, the $\mathrm{CO}_{2}$ was passed slowly into the cell, and the delivery tube fitted loosely in an oversize hole in the Parafilm seal. The hydrostatic pressure on the gas bubbles is negligible $(<0 \cdot 1 \%)$.

Calculations. The equilibrium was approached from both sides, and the concentration of NADPH at equilibrium was calculated from the change of extinction at $340 \mathrm{~m} \mu$. To allow for the small contribution by 2-oxoglutarate to absorption at this wavelength, an extinction coefficient of $6 \cdot 24 \times 10^{6} \mathrm{~cm} .{ }^{2} / \mathrm{mole}$ was used instead of the value of $6.22 \times 10^{6} \mathrm{~cm} .{ }^{2} /$ mole for NADPH (Horecker \& Kornberg, 1948). The partial pressure of $\mathrm{CO}_{2}$ was calculated from the barometric pressure and the saturated water-vapour pressure at the temperature of the experiment.

The equilibrium constant for the reaction:

$$
\begin{aligned}
& \mathrm{NADP}^{+}+\text {isocitrate }^{3-} \rightleftharpoons \\
& \mathrm{NADPH}+2 \text {-oxoglutarate } \\
& \text { 2- }+\mathrm{CO}_{2} \text { (gas) }
\end{aligned}
$$

was calculated from the equation :

$$
K_{p}=\frac{[\mathrm{NADPH}]\left[2-\text { oxoglutarate }^{2-}\right]}{\left[\mathrm{NADP}^{+}\right]\left[\text {isocitrate }^{3-}\right]} \times \frac{p}{760}
$$

where $p$ is the partial pressure of $\mathrm{CO}_{2}$ in $\mathrm{mm}$. $\mathrm{Hg}$. This equation can be applied for all ionic strengths, and extrapolation to zero ionic strength at $25^{\circ}$ gives the thermodynamic equilibrium constant, $K_{a}$, for reaction (1). The variation of $K_{p}$ with ionic strength will reflect the changing activity coefficients of dissolved ionic reactants only, and can be interpreted by the Debye-Hückel theory. The standard free-energy change for reaction (1) at $25^{\circ}$ was calculated from the reaction isotherm:

$$
-\Delta G^{0}=2 \cdot 303 R T \log K_{a}=1 \cdot 364 \log K_{a} \mathrm{kcal} . / \mathrm{mole}
$$

and refers to the usual standard states of unit activity of the ideal molar solution for dissolved reactants and $1 \mathrm{~atm}$. pressure for the pure gas. The enthalpy change for reaction (1) was calculated from the effect of temperature on $K_{p}$ with $I 0 \cdot 104$ by using the van't Hoff isochore:

$$
\mathrm{d}(\log K) / \mathrm{d}(1 / T)=-\Delta H / 2 \cdot 3 R
$$

In relation to kinetic and metabolic studies, the equilibrium constant for the reaction:

$$
\begin{aligned}
\mathrm{NADP}^{+}+\text {isocitrate }^{3-} \rightleftharpoons \mathrm{NADPH} & +2 \text {-oxoglutarate } \\
& 2- \\
& +\mathrm{CO}_{2} \text { (solution) }
\end{aligned}
$$

at a given ionic strength and temperature may be more useful than that for reaction (1), and was calculated from

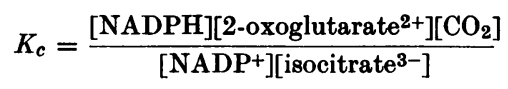

The dissolved $\mathrm{CO}_{2}$ concentration was estimated from the partial pressure and the data of Harned \& Davis (1943) for the solubility of $\mathrm{CO}_{2}$ in water and in $\mathrm{NaCl}$ solutions over a wide range of temperature. It was assumed that the solubilities of $\mathrm{CO}_{2}$ in reaction mixtures containing $\mathrm{KHCO}_{3}$ and $\mathrm{KCl}$ as the principle ionic species are the same as in $\mathrm{NaCl}$ solutions of the same ionic strength. This is not strictly true, but the error would be negligible over the range of ionic strength used, since the solubility of $\mathrm{CO}_{2}$ in $0.5 \mathrm{M}-\mathrm{NaCl}$ is only $10 \%$ less than in water.

Variation of $K_{c}$ with ionic strength will be partly due to variations of the activity coefficient of $\mathrm{CO}_{2}$. Extrapolation to zero ionic strength will give the thermodynamic equilibrium constant from which the standard free-energy change for reaction (3) could be calculated. This will refer to a standard state of unit activity of the ideal molar solution of $\mathrm{CO}_{2}$, as well as of other reactants. However, it is simpler and more accurate to calculate the standard free-energy change for reaction (3) from that for reaction (1) and that for:

$$
\mathrm{CO}_{2} \text { (gas) } \rightleftharpoons \mathrm{CO}_{2} \text { (solution) }
$$

The solubility of $\mathrm{CO}_{2}$ in pure water at $25^{\circ}$ is 0.0344 molal at $760 \mathrm{~mm}$. (Harned \& Davis, 1943), from which $\Delta G^{0}$ for reaction (5) is $-1 \cdot 364 \log 0 \cdot 0344=2 \cdot 00 \mathrm{kcal}$. $/$ mole (cf. Burton $\&$ Krebs, 1953). Similarly, the enthalpy change for reaction (3) will be the sum of that for reaction (1) and the heat of solution of $\mathrm{CO}_{2}$, which is $\Delta H^{0}=-4 \cdot 72 \mathrm{kcal} . / \mathrm{mole}$ (Harned \& Davis, 1943).

\section{RESULTS}

The results of equilibrium measurements at $25^{\circ}$ with $I 0 \cdot 104$ and $0 \cdot 133 \mathrm{~mm}$-magnesium sulphate are shown in Table 1. The equilibrium constant is independent of the reactant concentrations, but the average values obtained by approaching the equilibrium from the two sides differ by $10 \%$. The reason for this difference is not known. Although 
Table 1. Isocitrate dehydrogenase equilibrium in potassium hydrogen carbonate-potassium chloride solutions of ionic strength $0 \cdot 104$ and $\mathrm{pH} 6 \cdot 9-7 \cdot 2$ at $25^{\circ}$

Reaction mixtures also contained $0.133 \mathrm{~mm}_{-} \mathrm{MgSO}_{4}$. Equilibrium was approached from both sides: reaction mixtures contained initially either (A) NADP + , isocitrate and 2-oxoglutarate or (B) NADPH and 2-oxoglutarate. The concentrations stated are the equilibrium values. Values of $K_{p}$ are calculated from eqn. (2), and values of $K_{c}$ from eqn. (4). Concentrations of dissolved $\mathrm{CO}_{2}$ are calculated from $p$, the partial pressure of $\mathrm{CO}_{2}$, and the solubility data of Harned \& Davis (1943).

(A)

$\begin{array}{cccc}\begin{array}{c}\left.\mathrm{NADP}^{+}\right] \\ (\mu \mathrm{M})\end{array} & \begin{array}{c}{[\text { Isocitrate] }} \\ (\mu \mathrm{M})\end{array} & \begin{array}{c}\text { [NADPH] } \\ (\mu \mathrm{M})\end{array} & \begin{array}{c}\text { [2-Oxoglutarate] } \\ (\mu \mathrm{M})\end{array} \\ \mathbf{5 6 \cdot 3} & \mathbf{3 3 \cdot 7} & 44 \cdot 7 & 1058 \\ 56 \cdot 6 & 34 \cdot 0 & 44 \cdot 4 & 1057 \\ 52 \cdot 9 & 36 \cdot 2 & 44 \cdot 2 & 1087 \\ 54 \cdot 5 & 37 \cdot 8 & 42 \cdot 6 & 1086 \\ 33 \cdot 5 & 16 \cdot 8 & 63 \cdot 6 & 275 \\ 35 \cdot 7 & 19 \cdot 0 & 61 \cdot 4 & 273 \\ 13 \cdot 1 & 10 \cdot 8 & 36 \cdot 1 & 2086 \\ 13 \cdot 6 & 11 \cdot 3 & 35 \cdot 9 & 2101 \\ 13 \cdot 8 & 11 \cdot 4 & 35 \cdot 4 & 2080 \\ 13 \cdot 3 & 10 \cdot 9 & 35 \cdot 9 & 2080 \\ & & & \\ 40 \cdot 2 & 40 \cdot 2 & 45 \cdot 6 & 1003 \\ 40 \cdot 1 & 40 \cdot 1 & 45 \cdot 7 & 1003 \\ 25 \cdot 5 & 25 \cdot 5 & 60 \cdot 3 & 291 \\ 24 \cdot 8 & 24 \cdot 8 & 61 \cdot 0 & 292 \\ 10 \cdot 4 & 10 \cdot 4 & 27 \cdot 5 & 2002 \\ 10 \cdot 3 & 10 \cdot 3 & 27 \cdot 6 & 2002\end{array}$

$\boldsymbol{p}$
$(\mathbf{m m} . \mathbf{H g})$
$\mathbf{7 3 7}$
$\mathbf{7 3 7}$
$\mathbf{7 4 0}$
$\mathbf{7 4 0}$
$\mathbf{7 4 0}$
$\mathbf{7 4 0}$
$\mathbf{3 7 \cdot 3}$
$\mathbf{3 7 \cdot 3}$
$\mathbf{3 7} \cdot \mathbf{5}$
$\mathbf{3 7 \cdot 5}$

$\mathbf{7 4 0}$
$\mathbf{7 4 0}$
$\mathbf{7 4 0}$
$\mathbf{7 4 0}$
$\mathbf{3 7} \cdot \mathbf{9}$
$\mathbf{3 7} \cdot \mathbf{9}$

$\left[\mathrm{CO}_{2}\right]$
$(\mathrm{mM})$
32.4
$32 \cdot 4$
$32 \cdot 5$
$32 \cdot 5$
$32 \cdot 5$
$32 \cdot 5$
$1 \cdot 64$
$1 \cdot 64$
$1 \cdot 65$
$1 \cdot 65$
$M e a n$
$32 \cdot 5$
$32 \cdot 5$
$32 \cdot 5$
$32 \cdot 5$
$1 \cdot 66$
$1 \cdot 66$
Mean

$\begin{gathered}K_{\boldsymbol{p}} \\ \text { (atm.) }\end{gathered}$
$24 \cdot 2$
$23 \cdot 6$
$24 \cdot 4$
$21 \cdot 9$
$30 \cdot 2$
$24 \cdot 1$
$26 \cdot 1$
$24 \cdot 1$
$23 \cdot 1$
$25 \cdot 5$
$24 \cdot 7$
$27 \cdot 6$
$27 \cdot 8$
$26 \cdot 3$
$28 \cdot 2$
$25 \cdot 4$
$26 \cdot 0$
$26 \cdot 9$

$K_{c}$

(M)

$0 \cdot 81$

0.79

$0 \cdot 81$

0.72

1.00

$\mathbf{0 . 8 0}$

$0 \cdot 88$

0.81

0.78

$0 \cdot 85$

$0 \cdot 82$

0.92

$\mathbf{0 . 9 3}$

$0 \cdot 88$

0.93

$\mathbf{0} \cdot 85$

$0 \cdot 86$

0.90

Table 2. Isocitrate dehydrogenase equilibrium in potassium hydrogen carbonate-potassium chloride solutions of various ionic strengths and $\mathrm{pH} 6 \cdot 6-7 \cdot 2$ at $25^{\circ}$

\begin{tabular}{|c|c|c|c|c|c|c|c|c|c|c|}
\hline$I$ & $\mathrm{pH}$ & $\underset{(\mu \mathrm{M})}{\left[\mathrm{NADP}^{+}\right]}$ & $\begin{array}{c}\text { [Isocitrate] } \\
(\mu \mathrm{M})\end{array}$ & $\begin{array}{l}{[\mathrm{NADPH}]} \\
(\mu \mathrm{M})\end{array}$ & $\begin{array}{c}\text { [2-Oxoglutarate] } \\
(\mu \mathrm{M})\end{array}$ & $\begin{array}{c}p \\
(\mathrm{~mm} . \mathrm{Hg})\end{array}$ & $\begin{array}{l}{\left[\mathrm{CO}_{2}\right]} \\
(\mathrm{mM})\end{array}$ & $\begin{array}{c}K_{p} \\
\text { (atm.) }\end{array}$ & $\begin{array}{c}K_{p} \text { (av.) } \\
\text { (atm.) }\end{array}$ & $\begin{array}{c}K_{c} \text { (av.) } \\
(\mathrm{M})\end{array}$ \\
\hline 0.017 & $7 \cdot 2$ & $\begin{array}{r}13 \cdot 2 \\
12 \cdot 5 \\
9 \cdot 9 \\
9 \cdot 9\end{array}$ & $\begin{array}{r}10 \cdot 8 \\
10 \cdot 1 \\
9 \cdot 9 \\
9 \cdot 9\end{array}$ & $\begin{array}{l}36 \cdot 2 \\
36 \cdot 9 \\
28 \cdot 0 \\
28 \cdot 0\end{array}$ & $\begin{array}{l}2081 \\
2082 \\
2003 \\
2003\end{array}$ & $\begin{array}{l}\mathbf{3 7} \cdot 4 \\
\mathbf{3 7} \cdot 4 \\
\mathbf{3 7} \cdot \mathbf{9} \\
\mathbf{3 7 \cdot 9}\end{array}$ & $\begin{array}{l}1 \cdot 69 \\
1 \cdot 69 \\
1 \cdot 71 \\
1 \cdot 71\end{array}$ & $\left.\begin{array}{l}26 \cdot 0 \\
30 \cdot 0 \\
28 \cdot 6 \\
28 \cdot 6\end{array}\right\}$ & $28 \cdot 3$ & 0.93 \\
\hline $0 \cdot 054$ & $6 \cdot 6$ & $\begin{array}{l}50 \cdot 6 \\
49 \cdot 9 \\
34 \cdot 3 \\
35 \cdot 3\end{array}$ & $\begin{array}{l}37 \cdot 2 \\
36 \cdot 7 \\
34 \cdot 3 \\
35 \cdot 3\end{array}$ & $\begin{array}{l}46 \cdot 5 \\
46 \cdot 5 \\
36 \cdot 6 \\
36 \cdot 1\end{array}$ & $\begin{array}{r}1070 \\
1063 \\
974 \\
970\end{array}$ & $\begin{array}{l}733 \\
733 \\
719 \\
719\end{array}$ & $\begin{array}{l}32 \cdot 8 \\
32 \cdot 8 \\
32 \cdot 1 \\
32 \cdot 1\end{array}$ & $\left.\begin{array}{l}25 \cdot 5 \\
26 \cdot 0 \\
28 \cdot 7 \\
26 \cdot 6\end{array}\right\}$ & $26 \cdot 7$ & 0.90 \\
\hline $0 \cdot 104$ & $6 \cdot 9-7 \cdot 2$ & & & (see ${ }^{\prime}$ & Table 1) & & & & $25 \cdot 8$ & 0.86 \\
\hline $0 \cdot 254$ & $6 \cdot 9$ & $\begin{array}{l}53 \cdot 6 \\
52 \cdot 0 \\
37 \cdot 2 \\
36 \cdot 6\end{array}$ & $\begin{array}{l}40 \cdot 2 \\
38 \cdot 8 \\
37 \cdot 2 \\
36 \cdot 6\end{array}$ & $\begin{array}{l}43 \cdot 5 \\
44 \cdot 4 \\
34 \cdot 2 \\
34 \cdot 6\end{array}$ & $\begin{array}{r}1067 \\
1060 \\
978 \\
975\end{array}$ & $\begin{array}{l}729 \\
729 \\
720 \\
720\end{array}$ & $\begin{array}{l}30 \cdot 8 \\
30 \cdot 8 \\
30 \cdot 4 \\
30 \cdot 4\end{array}$ & $\left.\begin{array}{l}20 \cdot 7 \\
22 \cdot 4 \\
22 \cdot 9 \\
23 \cdot 9\end{array}\right\}$ & $22 \cdot 5$ & 0.72 \\
\hline 0.404 & $6 \cdot 9$ & $\begin{array}{l}\mathbf{5 6} \cdot 0 \\
\mathbf{5 3} \cdot \mathbf{3} \\
\mathbf{5 3} \cdot \mathbf{7} \\
\mathbf{3 7} \cdot \mathbf{4} \\
\mathbf{3 8} \cdot \mathbf{2}\end{array}$ & $\begin{array}{l}42 \cdot 6 \\
40 \cdot 1 \\
40 \cdot 5 \\
37 \cdot 4 \\
38 \cdot 2\end{array}$ & $\begin{array}{l}41 \cdot 1 \\
43 \cdot 1 \\
43 \cdot 0 \\
\mathbf{3 3} \cdot 5 \\
\mathbf{3 2} \cdot \mathbf{7}\end{array}$ & $\begin{array}{r}1064 \\
1059 \\
1063 \\
971 \\
970\end{array}$ & $\begin{array}{l}733 \\
733 \\
727 \\
719 \\
719\end{array}$ & $\begin{array}{l}29 \cdot 8 \\
29 \cdot 8 \\
29 \cdot 6 \\
29 \cdot 2 \\
29 \cdot 2\end{array}$ & $\left.\begin{array}{l}17 \cdot 7 \\
20 \cdot 6 \\
20 \cdot 1 \\
22 \cdot 0 \\
20 \cdot 6\end{array}\right\}$ & $20 \cdot 2$ & 0.62 \\
\hline
\end{tabular}

there was no evidence of coenzyme instability, in that the extinction at $340 \mathrm{~m} \mu$ remained constant after equilibrium was reached, it is possible that small losses of both coenzymes occur during the approach to equilibrium, and that the coenzyme added initially is degraded to slightly greater extent.

The results of equilibrium measurements with 


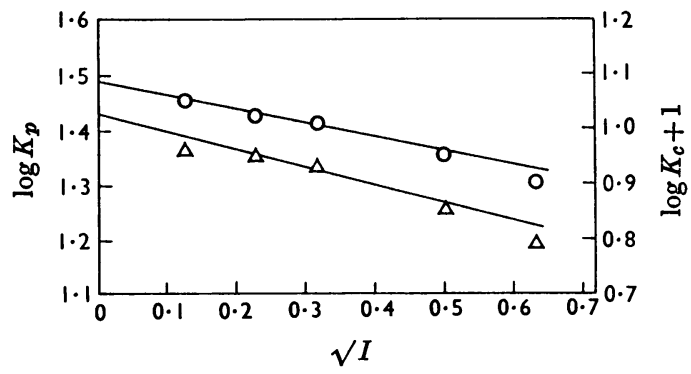

Fig. 1. Effect of ionic strength, $I$, on the equilibrium constants $K_{p}(O)$ and $K_{c}(\Delta)$ of the isocitrate dehydrogenase reaction at $25^{\circ} . K_{p}$ is defined by eqn. (2) and $K_{c}$ by eqn. (4). The data are from Tables 1 and 2.

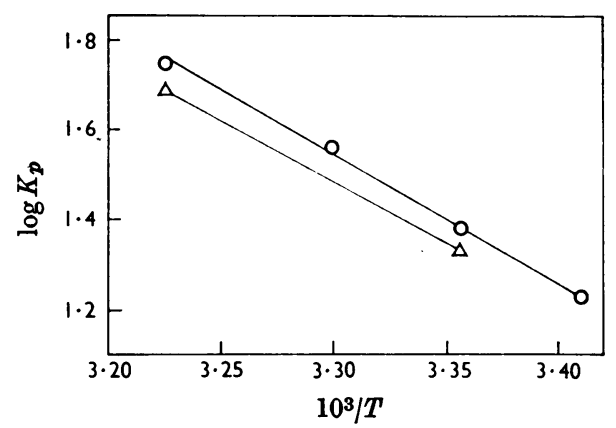

Fig. 2. Effect of temperature on the equilibrium constant, $K_{p}$, of the isocitrate dehydrogenase reaction, with $I 0.104$ (O) and $I 0 \cdot 254(\Delta)$.

other ionic strengths are shown in Table 2. The variation of $K_{p}$ with ionic strength is small. If plots of $\log K_{p}$ against $\sqrt{ } I$ (Fig. 1) are interpreted by the usual form of equation:

$$
\log K_{p}=\log K_{a}+A \sqrt{ } I
$$

then the intercept gives a value for $K_{a}$ at zero ionic strength and $25^{\circ}$ of $30.9 \mathrm{~atm}$., and the slope $A$ is $-0 \cdot 26$. A plot of $\log K_{c}$ against $\sqrt{ } I$ is also shown in Fig. 1.

Equilibrium measurements with $I$ 0.104 were made at three other temperatures, and with $I 0.254$ at $37^{\circ}$. The equilibrium was approached from the NADP + side. The results of these measurements, and those for $25^{\circ}$ from Table 1 , are shown as plots of $\log K_{p}$ against $1 / T$ in Fig. 2. From the slope with $I 0 \cdot 104$, the heat of reaction (1) is $13.75 \mathrm{kcal} . / \mathrm{mole}$. From this value, and the heat of solution of $\mathrm{CO}_{2},-4.72 \mathrm{kcal} . / \mathrm{mole}$ (Harned \& Davis, 1943), $\Delta H$ for reaction (3) is $9.03 \mathrm{kcal} . / \mathrm{mole}$.

The effect on $K_{p}$ of varying the concentration of magnesium sulphate in the reaction mixture, with

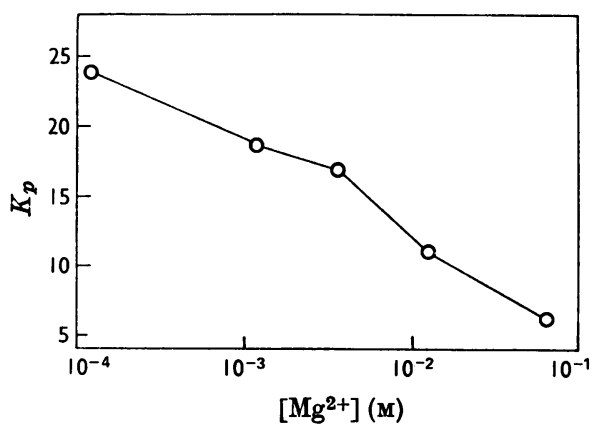

Fig. 3. Variation of the equilibrium constant of the isocitrate dehydrogenase reaction, $K_{p}$, with the logarithm of the concentration of $\mathrm{MgSO}_{4}$ in the reaction mixture. Values for $K_{p}$, calculated from eqn. (2), were corrected to constant $I$ $0 \cdot 104$ by means of the data of Fig. 1 .

constant potassium hydrogen carbonate and potassium chloride concentrations, is shown in Fig. 3. The values of $K_{p}$ were corrected to a constant ionic strength of 0.104 by means of the data of Fig. 1. There is evidently a considerable specific effect by high concentrations of magnesium sulphate on the equilibrium. For this reason the low concentration of $0.133 \mathrm{~mm}$, at which the specific effect is negligible, was used in all the experiments described above.

\section{DISCUSSION}

Ochoa (1948) obtained values for $K_{c}$ of $0.51-$ $1.02 \mathrm{M}$ with different reactant concentrations and ionic strengths ranging from 0.02 to 0.12 , at room temperature $\left(21-23^{\circ}\right)$. Large ratios of 2-oxoglutarate concentration to isocitrate concentration at equilibrium were needed to give accurately measurable ratios of oxidized to reduced coenzyme. The relatively small ionic-strength and temperature effects on $K_{c}$ demonstrated here show that lack of control of these factors cannot account for the variability of Ochoa's (1948) data. A large excess of 2-oxoglutarate over isocitrate could also be a source of considerable error if even small amounts of isocitrate or oxalosuccinate were present in the 2-oxoglutarate. Despite the variability, the mean value of $0.77 \mathrm{M}$ reported by Ochoa (1948) is in good agreement with that of $0.79 \mathrm{M}$ for $I 0.05$ and $22^{\circ}$ estimated from the results of the present experiments, in which larger carbon dioxide concentrations and smaller 2-oxoglutarate concentrations were used, and no significant variation of $K_{c}$ with the reactant concentrations at constant ionic strength was observed.

Ochoa (1948) assumed that dissolved $\mathrm{CO}_{2}$ is the product of the reaction. If the $\mathrm{HCO}_{3}$ - ion were the 
primary product, the true equilibrium constant of the isocitrate dehydrogenase reaction would be $K_{c} K_{1}^{\prime} /\left[\mathrm{H}_{2} \mathrm{O}\right]$, where:

$$
K_{1}^{\prime}=\frac{\left[\mathrm{H}^{+}\right]\left[\mathrm{HCO}_{3}^{-}\right]}{\left[\mathrm{CO}_{2}\right]+\left[\mathrm{H}_{2} \mathrm{CO}_{3}\right]}
$$

the apparent first ionization constant of carbonic acid. It has now been shown (Dalziel \& Londesborough, 1968) that $\mathrm{CO}_{2}$ is indeed the true substrate of isocitrate dehydrogenase (and of the 'malic' enzyme and 6-phosphogluconate dehydrogenase), and therefore eqn. (3) correctly describes the equilibrium, which is independent of the $\mathrm{H}^{+}$ ion concentration. Strictly, $K_{c}$ should be corrected for inclusion of $\mathrm{H}_{2} \mathrm{CO}_{3}$ in the dissolved $\mathrm{CO}_{2}$ concentration, but the correction is negligible since only $0 \cdot 1 \%$ of the total is hydrated.

The effect of ionic strength on the equilibrium is slight, compared with its effect on the glutamate dehydrogenase equilibrium, for example (Engel \& Dalziel, 1967). This is to be expected if the effects can be interpreted in terms of changes of the activity coefficients of the ionic reactants in accordance with the Debye-Hückel limiting law :

$$
\log \gamma=-0.5 Z^{2} \sqrt{ } I
$$

If the activity coefficients of the multivalent ions isocitrate $^{3-}$, 2-oxoglutarate ${ }^{2-}$ and $\mathrm{NADPH}^{4-}$ are calculated from this relation, then from the experimental value of $-\mathbf{0 . 2 6}$ for the slope of the plot of $\log K_{p}$ against $\sqrt{ } I$ (Fig. 1), the activity coefficient of the zwitterion NADP ${ }^{+4-}$ is given by:

$$
-\log \gamma=5 \cdot 76 \sqrt{ } I
$$

corresponding to an 'effective charge' of $\mathbf{- 3 \cdot 4}$. Although the application of the Debye-Hückel limiting law to large multivalent ions is of uncertain validity, this result may have value as an empirical description.

The thermodynamic equilibrium constant for reaction (1), obtained by extrapolation of $K_{p}$ to zero ionic strength, is $30.9 \mathrm{~atm}$., from which $\Delta G^{0}=-2.03 \mathrm{kcal} . / \mathrm{mole}$. From this value and the standard free energy of solution of $\mathrm{CO}_{2}, 2.00 \mathrm{kcal} . /$ mole (Burton \& Wilson, 1953), $\Delta G^{0}$ for reaction (3) is $-0.03 \mathrm{kcal} . / \mathrm{mole}$. Also, from $\Delta G^{0}=5.93 \mathrm{kcal}$./ mole for the reduction of NADP+ (Engel \& Dalziel, 1967), the standard free-energy change for the oxidative decarboxylation of isocitrate:

$$
\text { Isocitrate }{ }^{3-}+\mathrm{H}^{+} \rightarrow 2 \text {-oxoglutarate }{ }^{2-}+\mathrm{CO}_{2} \text { (gas) }
$$

is $-7.96 \mathrm{kcal} . / \mathrm{mole}$. Burton \& Wilson (1953) calculated a value for $\Delta G^{0}$ of $-12.69 \mathrm{kcal} . / \mathrm{mole}$ for this reaction from Ochoa's (1948) value for $K_{c}$ at $I \sim 0.05$, which was incorrectly reported as $0.77 \times$ $10^{4} \mathrm{M}$ (cf. Harary, Korey \& Ochoa, 1953). Related free-energy data derived by Burton \& Krebs (1953) contain the same error. This was corrected by Burton (1957), who calculated $\Delta G^{\prime}=2.32 \mathrm{kcal}$./ mole, corresponding to $\Delta G^{0}=7 \cdot 23 \mathrm{kcal} . / \mathrm{mole}$, for reaction (6). A value of $5.44 \mathrm{kcal} . / \mathrm{mole}$ for the free energy of reduction of NADP+ (Burton \& Wilson, 1953) was used in this calculation, which accounts for part of the discrepancy with the present value.

From $\Delta G^{0}=-7.96 \mathrm{kcal} . / \mathrm{mole}$ for reaction (6), and the standard free energy of reduction of $\mathrm{NAD}^{+}$, $5 \cdot 22 \mathrm{kcal} . / \mathrm{mole}$ (Burton \& Wilson, 1953), $\Delta G^{0}$ for the oxidative decarboxylation of isocitrate by $\mathrm{NAD}^{+}$ is $-2 \cdot 74 \mathrm{kcal} . / \mathrm{mole}$.

These and other free-energy data are summarized in Table 3. $\Delta G^{0}$ values refer to the usual standard

\section{Table 3. Free-energy data for the isocitrate dehydrogenase reaction}

The data are calculated from the equilibrium constant, $K_{p}$, for the NADP+-linked reaction measured in $\mathrm{KHCO}_{3}-$ $\mathrm{KCl}$ solution of various concentrations and extrapolated to zero ionic strength. $\Delta G^{0}$ values are for unit activity

\begin{tabular}{|c|c|c|c|c|c|c|}
\hline $\begin{array}{l}\text { Reactants or oxidant } \\
\qquad\left(+\mathrm{H}_{2} \text { gas }\right)\end{array}$ & $\begin{array}{l}\text { Products or } \\
\text { reductant }\end{array}$ & $\begin{array}{c}\Delta G^{0} \\
\text { (kcal./mole) }\end{array}$ & $\begin{array}{c}\Delta G^{\prime} \\
\text { (kcal./mole) }\end{array}$ & $\begin{array}{c}\Delta G^{\prime \prime} \\
\text { (kcal./mole) }\end{array}$ & $E_{0}^{\prime}(\mathrm{v})$ & $E_{0}^{\prime \prime}(\mathrm{v})$ \\
\hline $\begin{array}{l}\text { Isocitrate }^{3-}+ \\
\text { NADP }+\end{array}$ & $\begin{array}{l}\text { 2-Oxoglutarate }{ }^{2-}+ \\
\mathrm{NADPH}+\mathrm{CO}_{2}\end{array}$ & $-2 \cdot 03$ & $-2 \cdot 03$ & $-3 \cdot 80$ & $+0 \cdot 044$ & +0.083 \\
\hline $\mathrm{NADP}^{+}$ & $\mathrm{NADPH}+\mathrm{H}^{+}$ & $+5 \cdot 93^{*}$ & $-3 \cdot 62$ & $-3 \cdot 62$ & -0.335 & -0.335 \\
\hline $\begin{array}{l}\text { 2-Oxoglutarate }{ }^{2-}+ \\
\mathrm{CO}_{2}\end{array}$ & Isocitrate $^{3-}+\mathrm{H}^{+}$ & $+7 \cdot 96$ & $-1 \cdot 59$ & $+0 \cdot 18$ & $-0 \cdot 379$ & -0.418 \\
\hline $\begin{array}{l}\mathrm{NAD}^{+} \\
\text {Isocitrate }^{3-+} \mathrm{NAD}^{+}\end{array}$ & $\mathrm{NADH}+\mathrm{H}^{+}$ & $\begin{array}{l}+5 \cdot 22 \dagger \\
-2 \cdot 74\end{array}$ & $\begin{array}{l}-4 \cdot 33 \\
-2 \cdot 74\end{array}$ & $\begin{array}{l}-4 \cdot 33 \\
-4.51\end{array}$ & $\begin{array}{l}-0.320 \\
+0.059\end{array}$ & $\begin{array}{l}-0.320 \\
+0.098\end{array}$ \\
\hline
\end{tabular}
of all reactants in aqueous solution at $25^{\circ}$, except that $\mathrm{CO}_{2}$ is the gas at 1 atm. $\Delta G^{\prime}$ and $E_{0}^{\prime}$ refer to a standard state of the $\mathrm{H}^{+}$ion of $\mathrm{pH} 7 \cdot 0$, and $\Delta G^{\prime \prime}$ and $E_{0}^{\prime \prime}$ refer in addition to a standard state for $\mathrm{CO}_{2}$ of 0.05 atm. The calculation of these quantities from $\Delta G^{0}$ is described in the text. 
states of unit activity of the ideal molar solution for dissolved reactants and $1 \mathrm{~atm}$. pressure for $\mathrm{CO}_{2}$. Values for $\Delta G^{\prime}$ and $E_{0}{ }^{\prime}$ are calculated for an arbitrary standard state of $\mathrm{pH} \mathrm{7.0}$ for the $\mathrm{H}^{+}$ion, and $\Delta G^{\prime \prime}$ and $E_{0}{ }^{\prime \prime}$ for $\mathrm{pH} 7.0$ and a standard state of $\mathrm{CO}_{2}$ of $0.05 \mathrm{~atm}$., which approximate physiological conditions. The relationships used to calculate these quantities from $\Delta G^{0}$, at $25^{\circ}$ and with $\Delta G$ values in kcal./mole and $E_{0}$ values in volts, are:

$$
\begin{aligned}
\Delta G^{\prime} & =\Delta G^{0}-2 \cdot 303 R T(\mathrm{pH}) \\
& =\Delta G^{0}-9 \cdot 55 \text { (if } \mathrm{H}^{+} \text {is a product) } \\
\Delta G^{\prime \prime} & =\Delta G^{\prime}+2 \cdot 303 R T \log 0.05 \\
& =\Delta G^{\prime}-1 \cdot 77 \text { (if } \mathrm{CO}_{2} \text { is a product) } \\
E_{0}{ }^{\prime} & =-\frac{\Delta G^{\prime}}{2 F}-\frac{2 \cdot 303 R T(\mathrm{pH})}{F} \\
& =-0 \cdot 0217 \Delta G^{\prime}-0.414 \\
E_{0}{ }^{\prime \prime} & =E_{0}{ }^{\prime}-\frac{2 \cdot 303 R T \log 0.05}{2 F} \\
& =E_{0}{ }^{\prime}+0.039
\end{aligned}
$$

The specific effect of increasing magnesium sulphate concentrations on the isocitrate dehydrogenase equilibrium (Fig. 3) can be explained by complex-formation with isocitrate and 2-oxoglutarate, and indicates that the $\mathrm{Mg}^{2+}$ ion has greater affinity for isocitrate than for 2-oxoglutarate. Unfortunately, the stability constants for these $\mathrm{Mg}^{2+}$ ion complexes do not appear to be recorded, but those for the $\mathrm{Ca}^{2+}$ and $\mathrm{Sr}^{2+}$ ion complexes of isocitrate are greater than those for 2-oxoglutarate (Sillen \& Martell, 1964). The effect of formation of complexes of the substrates with $\mathrm{Mg}^{2+}$ ions on the equilibrium constant of the isocitrate dehydrogenase reaction should be described by:

$$
K_{\text {app. }}=\frac{K\left(1+K_{1}\left[\mathrm{Mg}^{2+}\right]\right)}{\left(1+K_{2}\left[\mathrm{Mg}^{2+}\right]\right)}
$$

where $K$ is the true equilibrium constant in the absence of $\mathrm{Mg}^{2+}$ ions, and $K_{1}$ and $K_{2}$ are the stability constants of the 2-oxoglutarate and isocitrate complexes respectively. The experimental results of Fig. 3 can be fairly well described by this equation if values of $K_{1}=60 \mathrm{M}^{-1}$ and $K_{2}=300 \mathrm{M}^{-1}$ are assumed. Although the data will not bear any firm conclusions, these values are reasonable in comparison with the available stability constants for complexes of bivalent metal ions with these and related acids (Sillen \& Martell, 1964).

At $37^{\circ}$ and with $I 0 \cdot 25$, which approximates conditions in liver tissue (Hohorst, 1960; Williamson, Lund \& Krebs, 1967), the values obtained for $K_{p}$ and $K_{c}$ are $48.9 \mathrm{~atm}$. and $1 \cdot 17 \mathrm{M}$ respectively. The values were obtained in the presence of $0.133 \mathrm{~mm}$ $\mathrm{Mg}^{2+}$ ion and would be smaller in the presence of larger concentrations of bivalent metal ion. $\mathrm{Mg}^{2+}$ ion is the predominant bivalent metal ion in the soft tissues, and its total concentration in most tissues is $10-20 \mathrm{~mm}$ (Widdowson \& Dickerson, 1964; Wacker \& Vallee, 1964). The concentration of free $\mathrm{Mg}^{2+}$ ions available for complex-formation with isocitrate and 2-oxoglutarate may be very small, however.

We are indebted to the Medical Research Council for financial support.

\section{REFERENCES}

Burton, K. (1957). Appendix in Energy Transformations in Living Matter by Krebs, H. A. \& Kornberg, H. L. Berlin : Springer-Verlag.

Burton, K. \& Krebs, H. A. (1953). Biochem. J. 54, 94.

Burton, K. \& Wilson, T. H. (1953). Biochem. J. 54, 86.

Dalziel, K. \& Dickinson, F. M. (1965). Biochem. J. 95, 311.

Dalziel, K. \& Londesborough, J. C. (1968). Biochem. J. $110,225$.

Engel, P. C. \& Dalziel, K. (1967). Biochem. J. 105, 691.

Harary, I., Korey, S. R. \& Ochoa, S. (1953). J. biol. Chem. 203, 595.

Harned, H. S. \& Davis, R. (1943). J. Amer. chem. Soc. 65, 2030.

Hohorst, H. J. (1960). Inaugural Dissertation: University of Marburg.

Horecker, B. L. \& Kornberg, A. (1948). J. biol. Chem. 175, 385.

Ochoa, S. (1948). J. biol. Chem. 174, 133.

Rose, Z. B. (1960). J. biol. Chem. 235, 928.

Siebert, G., Dubuc, J., Warner, R. C. \& Plaut, G. W. E. (1957). J. biol. Chem. 226, 965.

Sillen, L. B. \& Martell, A. E. (1964). Stability Constants of Metal Ion Complexes. London: The Chemical Society.

Wacker, W. E. C. \& Vallee, B. L. (1964). In Mineral Metabolism, vol. 2, part A, p. 483 . Ed. by Comar, C. L. \& Bronner, F. New York: Academic Press Inc.

Widdowson, E. M. \& Dickerson, J. W. T. (1964). In Mineral Metabolism, vol. 2, part A, p. 2. Ed. by Comar, C. L. \& Bronner, F. New York: Academic Press Inc.

Williamson, D. H., Lund, P.\& Krebs, H. A. (1967). Biochem. $J .103,514$. 